\title{
RAMADAN EFFECT AND VOLATILITY RISK BY GARCH MODEL: EVIDENCE IN INDONESIA STOCK MARKET
}

\author{
Dery Westryananda Putra \\ Bandar Lampung, Lampung \\ dery011@live.com
}

\begin{abstract}
Sri Hasnawati ${ }^{a}$ dan Muslimin ${ }^{b}$
Management, Department, Faculty of Economics and Business University of Lampung sri.hasna2015@gmail.com ${ }^{a l \rtimes}$, muslimin.1975@feb.unila.ac.id ${ }^{b}$
\end{abstract}

\begin{abstract}
ABSTRAK
Penelitian ini bertujuan untuk menganalisis pengaruh Ramadhan effect dan risiko volatilitas terhadap pasar saham Indonesia dengan menggunakan model GARCH. Populasi dalam penelitian ini adalah perusahaan yang terdaftar pada indeks LQ45 di Bursa Efek Indonesia selama tahun 2019. Terdapat 42 perusahaan yang dijadikan sampel dalam penelitian ini. Sampel penelitian diambil dengan menggunakan metode purposive sampling. Penelitian ini menggunakan model GARCH sebagai alat analisis. Hasil penelitian ini menunjukkan bahwa tidak ada pengaruh Ramadhan terhadap indeks LQ45, namun volatilitas pada bulan Ramadhan berpengaruh terhadap volatilitas pada indeks LQ45.
\end{abstract}

Kata Kunci: Ramadhan Effect, Risiko Volatilitas, Model GARCH

\begin{abstract}
This study aims to analyze the effect of the Ramadan effect and volatility risk on the Indonesian stock market using the GARCH model. The population in this study are companies listed on the LQ45 index on the Indonesia Stock Exchange during 2019. There are 42 companies used as samples in this study. The research sample was taken using purposive sampling method. This study uses the GARCH model as an analytical tool. The results of this study indicate that there is no Ramadan effect on the LQ45 index, but the volatility in the month of Ramadan affects the volatility in the LQ45 index.
\end{abstract}

Keywords: Ramadan Effect, Volatility Risk, GARCH Model

\section{INTRODUCTION}

One of the terms most often mentioned in the economic world is investment. Investment is a delay in consumption now to be included in productive assets for a certain period of time (Hartono, 2017). According to Tandelilin (2010), investment is a commitment to a number of funds or other resources made at this time, with the aim of obtaining a number of benefits in the future. Investments can be done in various ways, one of which is investing in the capital market. Capital market is a market for a variety of long-term financial instruments that can be traded, both bonds, equities (stocks), mutual funds, derivative instruments and other instruments.

The capital market is a place where investors and capital borrowers meet. In the Indonesian capital market, there are more than 650 companies and these companies are contested by various investors both from outside the country and within the country. The

\footnotetext{
${ }^{1} \rtimes$ : Corresponding author: sri.hasna2015@gmail.com
} 
availability of information will certainly affect the capital market. According to Fama (1970) that the market will be said to be efficient if the prices formed in the market are a reflection of the available information, so that a hypothesis is formed that is Efficient Market Hypothesis (EMH). Deviations from efficient capital markets are called Market Anomaly. Market anomalies are distortions in returns that contradict the efficient market hypothesis $(\mathrm{EMH})$. The calendar effect is the one of seasonal anomalies that refers to changes in the market price or market index due to how specific days, months or times of the year relate to prices of commodities in the market.

Indonesia, as the country with the largest Muslim population in Southeast Asia, celebrates Eid al-Fitr and establishes Eid as a national holiday. Before celebrating Eid alFitr, Muslims around the world perform fasting in the month of Ramadan. The presence of Ramadan in Indonesia has changed the behavior of Indonesian people, starting from the level of daily consumption and working hours that change. Changing public behavior and changes in productive working hours and the effect of holidays at the end of the month of Ramadan can cause abnormal returns on the Indonesia Stock Exchange. A long holiday at the end of the month of Ramadan and the Lebaran Mudik tradition will influence investors to resell their shares to buy the needs of Eid at home.

Hassan and Kayser (2019) conducted a study to prove whether there is a Ramadan effect on the Dhaka Stock Exchange (DSE), Bangladesh. The result concludes that Ramadan month has doesn't have a significant relationship with stock market returns and volatility. The research from Lai and Windawati (2017) about risk, return, and liquidity of Indonesian and Malaysian stock markets during Ramadan has several conclusions are as follows: riskadjusted returns for each country do not significantly change during Ramadan, the return volatility is higher either during Ramadan for Indonesia stock market, except for the Indonesia Islamic Index the stock market become more liquid during Ramadan.

Changes in investor behavior can trigger changes in trends of the capital market. Stock prices will fluctuate and the level of risk will change. To measure the level of fluctuation and risk of a stock, one important component is Volatility. Volatility is a statistical measure of the dispersion of returns for a given security or market index. In most cases, the higher the volatility, the riskier the security. Volatility is often measured as either the standard deviation or variance between returns from the same security or market index. Volatility also can be measured with beta coefficient and option pricing model. There are 2 types of calculation of volatility, the autoregressive method and the moving average. In this method there are several models namely ARCH (Autoregressive Conditional Heteroscedasicity), ARMA (Autoregressive Moving Average), ARIMA (Autoregressive Integrated Moving Average), and GARCH (Generalized Autoregressive Conditional Heteroscedasticity). The GARCH model is a development of the ARCH model invented by Engle (1982). The GARCH model developed by Bollerslev in 1986 and became the method most often used in analyzing volatility. GARCH analyzes time-series data where the variance error is believed to be serially autocorrelated.

\section{LITERATURE REVIEW}

\section{Stock Market}

According to law number 8 of 1995 concerning capital markets article 1 paragraph 13 that the capital market is an activity concerned with public offering and trading of securities, public companies related to securities issued, and institutions and professions related to securities. Some instruments traded in the capital market include: stocks, bonds, mutual funds, exchange traded funds, and derivatives. Shares are securities of company ownership. Bonds are securities or certificates that state that the purchaser of the bonds has 
given debt to the party that issued the bonds. Mutual funds are a container that is used to collect funds from the community of investors to subsequently be invested in a portfolio of securities by investment managers (capital market law no. 8 of 1995, article 1 paragraph 27).

\section{Efficient Market Hypothesis}

Efficiency of capital markets or efficient markets is a market where the prices of all traded securities have reflected all available information (Tandelilin, 2010). According to Fama (1970) that the market will be said to be efficient if the prices formed in the market are a reflection of the available information, so that a hypothesis is formed that is Efficient Market Hypothesis (EMH). Fama (1970) classifies efficient market forms into three forms, namely weak form efficiency, semi strong efficiency, and strong efficiency.

The information can come from internal or external. Internal information includes changes in daily stock prices and fundamental analysis of a company. External information includes all information that comes from outside the company such as the state of the country's economy and the current world situation.

\section{Market Anomaly}

According to Jones (1996) in Hartono (2017), market anomaly as a form of strategy or technique because the results generated by this market anomaly allow investors to get the opportunity to obtain abnormal profits by relying on various events that occur in the capital market.

Almudhaf (2012) in Nasir (2017) investigates the Islamic calendar seasonal effects in the stock returns of 12 countries where Muslims form the majority of the population. The results showed evidence of Islamic calendar seasonal effects in all 12 countries of the sample. In the month of Ramadan, Jordan, Kuwait, Pakistan and Turkey have a positive Ramadan effect existed in these countries which opposes as some investors predicted. Surprisingly, for all 12 countries, there is a positive coefficient during the month of Ramadan. Based on the results, there is an average Ramadan return which exceeds the average months in the other months of the Islamic calendar in the four countries mentioned earlier. Their final results showed evidence of seasonality in stock returns based on the Islamic calendar.

\section{Volatility}

Volatility is a statistical measurement for price fluctuations during a certain period (Firmansyah, 2006). This measure shows the decline and increase in prices in a short period and does not measure the price level, but the degree of variation from one period to the next. The ability of investors to predict whether or not there is stock price volatility will affect the returns that will be obtained by investors. According to (Kartika, 2010) the existence of volatility will lead to greater risks and uncertainties faced by investors so that investor interest in investing becomes unstable.

\section{Risk}

According to Hanafi (2006), the definition of risk is danger, the consequences or consequences that can occur due to an ongoing process or events that will come. In a financial context, risk is the potential loss that can happen in the future. There are two types of risk, the first is pure risk and the second is speculative risk. Pure risk is the risk that if it occurs will inevitably lead to losses and if it does not occur there will be no loss or profit generated. 


\section{Generalized Autoregressive Conditional Heteroscedasticity}

Bollerslev (1986) developed the Generalized Autoregressive Conditional Heteroscedasticity (GARCH) model from a model discovered by Engle (1982), the Autoregressive Conditional Heteroscedasticity (ARCH) model. In the ARCH model found by Engle (1982), the conditional variance (ht) depends on the last mass squared residual with the following formula:

$$
h_{t}=\alpha_{0}+\sum_{i}^{q} \alpha_{i} \varepsilon_{t-i}^{2}
$$

Then Bollerslev (1986) developed the ARCH model to be more practical and flexible by making ht as a function of the lag value of ht itself at once the lag value of $\varepsilon t 2$. Allowing for a much more flexible lag structure. The extension of the ARCH process to the GARCH process bears much resemblance to the extension of the standard time series AR process to the general ARMA process and, as is argued below, permits a more parsimonious description in many situations. According to Engle (2001), The GARCH model that has been described is typically called the $\operatorname{GARCH}(1,1)$ model. The $(1,1)$ in parentheses is a standard notation in which the first number refers to how many autoregressive lags, or ARCH terms, appear in the equation, while the second number refers to how many moving average lags are specified, which here is often called the number of GARCH terms. Sometimes models with more than one lag are needed to find good variance forecasts.

\section{RESEARCH METHOD}

\section{Population and Sample}

The population in this study is companies listed on the Indonesia Stock Exchange in the LQ45 index during the period January 2019 to December 2019. The sampling technique in this study is purposive sampling that is taking a sample from the population based on a certain criterion (Hartono, 2017). The criteria in this study are the stocks must be listed in the LQ45 index continuously from period 2019. From these criteria, we start from collecting the data from 30 days before Ramadan month until 30 days after Ramadan month in 2019 and finally obtained 42 samples of stock in LQ45 Index over a period of one year.

\section{Dependent Variable (Y)}

Sekaran (2016) explains that the dependent variable is the variable of primary interest to the researcher. The researcher's goal is to understand and describe the dependent variable, or to explain its variability, or predict it. The dependent variable in this research is stock return and to measure the return we can use the formula as follows:

Where:

$$
R i_{t}=\frac{\left(P_{t}-P_{t-1}\right)}{P_{t-1}}
$$

$\mathrm{Ri}_{\mathrm{t}} \quad$ : Return at time $\mathrm{t}$

$\mathrm{P}_{\mathrm{t}} \quad$ : Invesment price at time $\mathrm{t}$

$\mathrm{P}_{\mathrm{t}-1} \quad$ : Investment price at the time of $\mathrm{t}-1$

In the formula above, dividends are not included in the formulation because the return data used in this study are daily returns while the dividends are not distributed every day and the dividend distribution schedule differs for each share. 


\section{Independent Variable $(\mathrm{X})$}

Sekaran (2016) explains that independent variable is the one that influences the dependent variable in either a positive or negative way. That is when the independent variable is present, the dependent variable is also present, and with each unit of increase in the independent variable, there is an increase or decrease in the dependent variable. The independent variable of this research is Volatility Risk.

Volatility risk can be measured using beta. According to Jogiyanto (2017) the formulation of beta as follows:

Where:

$$
\text { Beta } \operatorname{coefficient}(\beta)=\frac{\sigma i M}{\sigma M^{3}}
$$

$\sigma \mathrm{iM}=$ Covariance of the return-i with market return

$\sigma \mathrm{M}^{2} \quad=$ Varians of the market return

Beta $(\beta)$ is a measure of the systematic risk of a stock or portfolio relative to market risk. Standard deviations and variants can also measure volatility. Volatility is a fluctuation in the return of a stock or portfolio in a given period, if statistically the fluctuations follow fluctuations in market returns, then beta of securities is one (Hartono, 2017). While the standard deviation and variance is a measurement of the spread between numbers in a data set.

\section{Data Analysis}

Data analysis used in this research is using GARCH model. The first formulation in this model uses the Autoregressive (AR) formula so that it can predict current or future returns using previous returns or past returns. The formulation is as follows:

Where as:

$$
R_{t}=\alpha_{0}+\alpha_{1} R_{t-1}+\alpha_{2} D_{-} R A M_{t}+\varepsilon_{t}
$$

$$
\begin{aligned}
& \alpha_{0} \quad=\text { Constant } \\
& \text { Rt }=\text { Return at time } \mathrm{t} \\
& \text { Rt-1 = Return at time t-1 } \\
& \text { D_RAMt = the dummy variable for Ramadan }
\end{aligned}
$$

The second formulation is the variance equation to measure the effect of the month of Ramadan on volatility. The variance equation above shows the GARCH model to see the volatility. The formulation as follows:

Where as:

$$
h_{t}=\beta_{0}+\beta_{1} \varepsilon_{t-1}^{2}+\beta_{2} h_{t-1}+\beta_{3} D_{-} R A M_{t}
$$

$$
\begin{array}{ll}
\beta_{0} & =\text { Constant } \\
\mathrm{ht} & =\text { Variance at time t } \\
\varepsilon_{\boldsymbol{t}-\mathbf{1}}^{2} & =\text { Squared error term at time t-1 (ARCH term) } \\
\text { ht-1 } & =\text { Variance at time } \mathrm{t}-1 \text { (GARCH term) } \\
\text { D_RAMt } & =\text { the dummy variable for Ramadan }
\end{array}
$$

The equation (1) is the mean equation on this model including Rt-1 as the return on the day before, $\varepsilon_{t}$ represent the error term while the $\alpha_{0}$ is constant, $\mathrm{RAM}_{t}$ is the dummy variable for the Ramadan month. In this equation will represent the influence of the return in Ramadan month. 
The equation (2) is the variance equation including the linear function of the last period's squared errors $\left(\varepsilon_{t-1}^{2}\right.$, as the ARCH term) and its own lagged conditional variance $\left(\mathrm{h}_{\mathrm{t}-1}\right.$ as the GARCH term), and $\mathrm{RAM}_{\mathrm{t}}$ is the dummy variable for the Ramadan month. This equation will represent the influence of the volatility in Ramadan month. After the data has been analysed, the hypothesis will be tested using z-test.

\section{RESULT}

\section{Descriptive Analysis}

Table 4.1 is a descriptive statistical information on the variables in this study with a total of 3780 observational data consisting of the return data of 42 companies listed on the LQ45 index for 90 days. The RETURN variable has a minimum value of -0.25 originating from companies with the MNCN on June 17, 2019, while the maximum value is 0.254682 originating from companies with INDY on June 25, 2019. The majority of LQ 45 stock returns from 1 May 2019 to 17 May 2019 experienced a decline which at that time was 2 days before Ramadan until 2 weeks during Ramadan.

Table 4.2 it can be seen that the mean of return has increased from 30 days before Ramadan until 30 days after Ramadan, from -0.0010 to 0.0025 . The mean of return is only positive in 30 days after Ramadan, but during Ramadan and 30 days before Ramadan the mean of return is negative. The standard deviation also tends to increase from 30 days before Ramadan to 30 days after Ramadan, from 0.0184 to 0.0240 . This shows an increase in the spread of data from returns every day.

Table 4.1 Descriptive Statistic of Return of LQ 45 Index for the Period 2019

\begin{tabular}{|l|c|}
\hline & RETURN \\
\hline Mean & 0.000168 \\
\hline Median & 0.000000 \\
\hline Maximum & 0.254682 \\
\hline Minimum & -0.250000 \\
\hline Std. Dev. & 0.022244 \\
\hline Skewness & 0.595282 \\
\hline Kurtosis & 23.28347 \\
\hline Source: Data processed using Eviews 10 \\
\hline
\end{tabular}

Table 4.2 Descriptive Statistic of Return in 3 Different Separation

\begin{tabular}{|l|c|c|c|}
\hline Mean & 30_DAYS_AFTER & RAMADAN & _30_DAYS_BEFORE \\
\hline Median & 0.002254 & -0.000691 & -0.001057 \\
\hline Maximum & 0.000000 & 0.000000 & 0.000000 \\
\hline Minimum & 0.254682 & 0.137500 & 0.081712 \\
\hline Std. Dev. & -0.250000 & -0.154891 & -0.220690 \\
\hline Skewness & 0.024050 & 0.023688 & 0.018413 \\
\hline Kurtosis & 1.904203 & 0.075764 & -1.402517 \\
\hline \multicolumn{2}{|c|}{ Source: Data processed using Eviews 10 } & 9.267116 & 21.58418 \\
\hline
\end{tabular}

\section{Stationary Test}

In this research stationary test or unit root test using Augmented Dickey-Fuller Test or what is often called the ADF Test. The following are the results of the Augmented DickeyFuller Test. Table 4.3 above shows that the p-value of the unit root test using the Augmented Dickey-Fuller test is 0.0000 for the variable Return at critical values of $1 \%, 5 \%$, and $10 \%$. These results explain that that the data in this study are stationary data. Table 4.4 above 
shows that the p-value of chi square using the ARCH-LM test is 0.0000 for variable returns. The result of this value explains that the data in this study are heteroscedasticity data and have an ARCH element.

Table 4.3 Augmented Dickey-Fuller Test of the Return Data

\begin{tabular}{|l|l|l|}
\hline Variable & t-Statistic & Prob. \\
\hline RETURN & -40.69675 & 0.0000 \\
\hline
\end{tabular}

Source: Data processed using Eviews 10

Table 4.4 Heteroscedasticity Test using ARCH-LM

\begin{tabular}{|l|l|}
\hline F-statistic & 113.1809 \\
\hline Obs*R-squared & 109.9462 \\
\hline Prob. Chi-Square(1) & 0.0000 \\
\hline
\end{tabular}

Source: Data processed using Eviews 10

\section{GARCH Test}

Table 4.5, the output in the mean equation with the variable RETURNT_1 has a pvalue of 0.0000 which means that the return t-1 on the LQ45 Indonesia Stock Exchange index has an effect on returns on the LQ45 Indonesia Stock Exchange index with a value of 0.345 , but in the D_RAM variable it is a variable the dummy from the month of Ramadan has a p-value of 0.8563 , which means that the return in the month of Ramadan on the LQ45 Indonesia Stock Exchange index has no effect on returns on the LQ45 Indonesia Stock Exchange index.

Table 4.5 Mean Equation Result of GARCH Test

\begin{tabular}{|l|l|l|l|l|}
\hline Variable & Coefficient & Std. Error & Z-Statistic & Prob \\
\hline C & 0.00508 & 0.00152 & 3.339879 & 0.0008 \\
\hline RETURN T-1 & 0.345461 & 0.002443 & 141.4233 & 0.0000 \\
\hline D_RAM & $5.74 \mathrm{E}-05$ & 0.000317 & 0.181094 & 0.8563 \\
\hline
\end{tabular}

Source: Data processed using Eviews 10

While the output in the variance equation section at table 4.6 is the result of the analysis referring to volatility. The variable GARCH (-1) has a p-value of 0.0310 , which means that past volatility in the LQ45 Indonesia Stock Exchange index has an effect on volatility in the LQ45 Indonesia Stock Exchange index with a value of 0.004685. The D_RAM variable, which is the dummy variable for the month of Ramadan, has a p-value of 0.0000 , which means that the volatility in the month of Ramadan in the LQ45 Indonesia Stock Exchange index affects the volatility in the Indonesia Stock Exchange index with a value of $7.36 \mathrm{E}-5(0.00000736)$.

Table 4.6 Variance Equation Result of GARCH Test

\begin{tabular}{|l|l|l|l|l|}
\hline Variable & Coefficient & Std. Error & z-Statistic & Prob. \\
\hline C & & & & \\
\hline RESID(-1)^2 & 0.000134 & $3.16 \mathrm{E}-06$ & 42.46542 & 0.0000 \\
\hline GARCH(-1) & 1.383857 & 0.052812 & 26.20335 & 0.0000 \\
\hline D_RAM & 0.004685 & 0.002172 & 2.157389 & 0.0310 \\
\hline
\end{tabular}

Source: Data processed using Eviews 10 
The output table has two parts, namely part 1 the mean equation with the formula:

$$
R_{t}=0.000508+0.345361 R_{t-1}+0.000057 R A M_{t}+\varepsilon_{t}
$$

And part 2 the variance equation with the formula:

$$
h_{t}=0.000134+1.383857 \varepsilon_{t-1}^{2}+0.004685 h_{t-1}+0.000073 R A M_{t}
$$

\section{ARCH-LM Residual Test}

Table 4.6 above shows that the p-value of chi square using the ARCH-LM test is 0.0684 . The result of this value explains that the output of the GARCH model is a valid result.

Table 4.7 Residual Test using ARCH-LM

\begin{tabular}{|l|l|}
\hline F-statistic & 3.322171 \\
\hline Obs*R-squared & 3.321009 \\
\hline Prob. Chi-Square(1) & 0.0684 \\
\hline
\end{tabular}

Source: Data processed using Eviews 10

\section{Hypothesis Testing}

Hypothesis testing in this study uses the $\mathrm{Z}$-Test. The $\mathrm{Z}$ test can be used to test data with large samples. In testing this hypothesis, there are several criteria, namely:

A. If $\mathrm{p}$-value $<0.05$, then there is a relationship between variables (Ha accepted)

B. If $p$-value $>0.05$, then there is no relationship between variables (Ha rejected)

The significance value or p-value used in this study is 95 percent or 0.95 so that the error tolerance limit used in this study is 5 percent or 0.05 .

Table 4.8 Hyphothesis Testing using Z-Test

\begin{tabular}{|c|c|c|c|c|c|}
\hline & Variable & Coefficient & Std. Error & z-Statistic & Prob. \\
\hline Mean Equation & DUMMY & $5.74 \mathrm{E}-05$ & 0.000317 & 0.181094 & 0.8563 \\
\hline Variance Equation & DUMMY & $7.36 \mathrm{E}-05$ & $8.27 \mathrm{E}-06$ & 8.901945 & 0.0000 \\
\hline
\end{tabular}

According to table above, the result of the hypothesis testing as follows:

1. According to the GARCH model in the mean equation, this section is the part to determine whether the Ramadan month has no significant influence to return of the Indonesia Stock Market. To determine this, see the DUMMY variable which has a probability value of 0.8563 . This value is greater than the significant value used in this study $(0.8536>0.05)$. This explains that Ramadan month has no significant influence to return of the Indonesia Stock Market. Ha1 is rejected.

2. According to the GARCH model in the variance equation section, this section is the part to determine whether the Ramadan month has no significant influence to the volatility of the Indonesia Stock Market. To determine this, it can be seen from the DUMMY variable which has a probability value of 0.0000 . This value is smaller than the significant value used in this study $(0.0000<0.05)$. This explains that Ramadan month has a significant influence to the volatility of the Indonesia Stock Market. Ha2 is accepted. 


\section{DISCUSSION}

\section{The Influence of Ramadan Month to Return of Indonesia Stock Market}

Referring to table 4.5, the p-value of the DUMMY variable has a value of 0.8563 and this value is greater than the error tolerance value of 0.05 . In this case, it explains that the month of Ramadan does not have a significant effect on returns on the Indonesia Stock Market. This is in line with the descriptive statistical table, the mean or average of return before Ramadan, during Ramadan, and after Ramadan tends to be stable. The average return on 30 days before the month of Ramadan with the month of Ramadan is only different from 0.000366 and tends to be negative. The average return during the month of Ramadan with 30 days after Ramadan is only different from 0.001563 . Thus, returns in the months before Ramadan, during Ramadan, and after Ramadan tend to be stable and there is no Ramadan effect on the Indonesia Stock Market.

\section{The Influence of Ramadan Month in Volatiliy to Indonesia Stock Market}

Referring to table 4.5, the p-value of the DUMMY variable has a value of 0.0000 and this value is smaller than the error tolerance value of 0.05 . This explains that the month of Ramadan has a significant effect on volatility on the Indonesia Stock Market. This is in line with the LQ45 return chart in the appendix. The graph shows that the return in the month of Ramadan is different every week and some even every day. In figure 4.1 show the average return in the month of Ramadan varies widely every day. From the first day (6 May 2019) with an average return of -0.015 , then an increase on the second day (7 May 2019) with an average return of 0.006 , but on the third day (8 May 2019) the average return decreased to 0.009 and so on.

This is also supported by descriptive statistical analysis on returns of 30 days before Ramadan, during Ramadan, and 30 days after Ramadan. In the descriptive analysis, it can be seen that the standard deviation of 30 days before Ramadan is different from the standard deviation in Ramadan and tends to increase. The standard deviation during Ramadan and 30 days after Ramadan tends to be the same. So that the month of Ramadan in 2019 has an influence on volatility in the LQ45 index because the volatility in Ramadan can affect the volatility in other months during period.

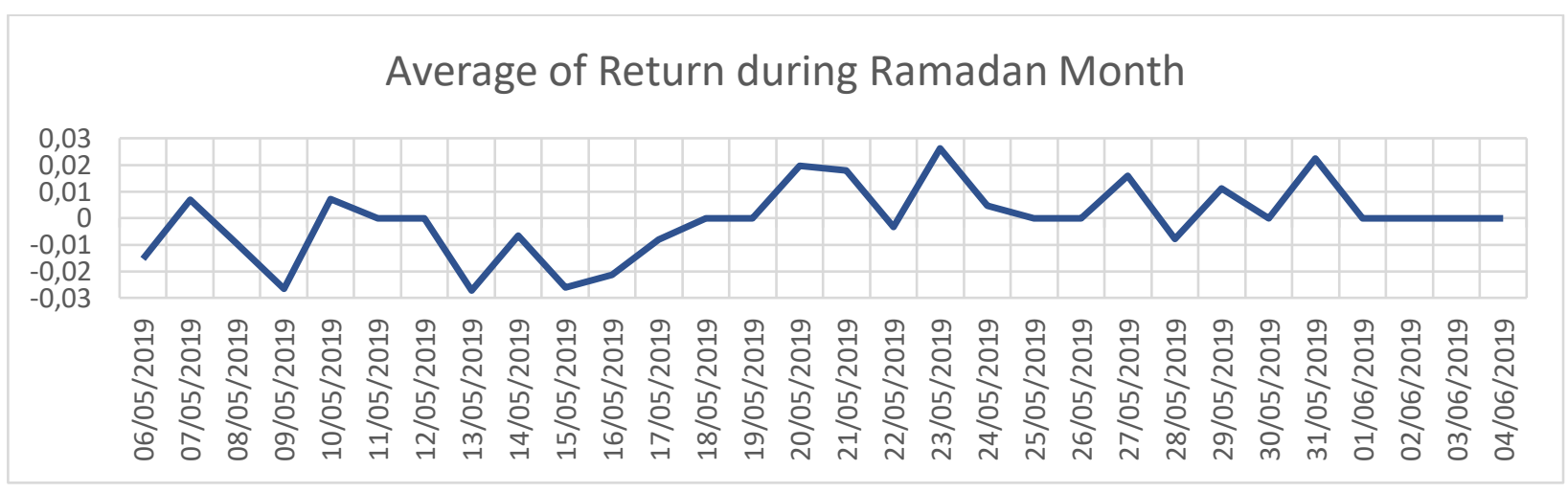

Source: Data processed from Microsoft

Figure 4.1 Average Return on Ramadan Graph

\section{CONCLUSION}

1. In the analysis of the first hypothesis, it is stated that the month of Ramadan does not have a significant effect on returns on the Indonesia Stock Market. 
2. In the second hypothesis analysis, it is stated that the month of Ramadan has a significant effect on volatility on the Indonesia Stock Market

Based on the above conclusions, it can be concluded that the month of Ramadan in the Indonesia Stock Market has no effect on returns but has an influence on volatility. With the composition of investors in Indonesia which is still dominated by foreign investors, it can be assumed that investors in Indonesia do not really care about the month of Ramadan so that investors in Indonesia are not too ambitious to take profits during Ramadan. Based on Rhee and Wang (2009) in Lai and Windawati (2017) the dominance of foreign investors and ownership promotes buy-and-hold strategy and increases information asymmetry and in the month of Ramadan 2019 to coincide with the day of the announcement of the presidential election of the Republic of Indonesia, it can be assumed that this situation can affect volatility in the Indonesian Stock Market.

\section{Research Limitation}

This research has limitations or shortcomings that need to be corrected in future studies, because the essence of this research is expected to be a reference in further research or as a support for another research. This limitation is that the study period is too short to allow for future biased results. So that for further research, it is hoped that researchers can increase the number of research periods so that accurate results can be obtained for the longterm trend.

\section{REFERENCE}

Akbalik, M., \& Tunay, K. (2016). An Analysis of Ramadan Effect by GJR-GARCH Model: Case of Borsa Istanbul. Oeconomia Copernicana.

Akther, A., Sandhu, A., \& Butt, S. (2015). Islamic Calendar Effect on Market Risk and Return Evidence from Islamic Countries. Journal of Business \& Financial Affairs.

Bollerslev, T. (1986). Generalized Autoregressive Conditional Heteroskedasticity. Journal of Econometrics, Vol. 31 page 307-327.

Eliyawati, W. Y., Hidayat, R., \& Azizah, D. F. (2014). Penerapan Model GARCH (Generalized Autoregressive Conditional Heteroscedasticity) untuk Menguji Pasar Modal Efisien di Indonesia (Studi pada Harga Penutupan (Closing Price) Indeks Saham LQ 45 Periode 2009-2011). Jurnal Administrasi Bisnis (JAB).

Engle, R. (2001). GARCH 101: The Use of ARCH/GARCH Models in Applied Econometrics. Journal of Economic Perspectives, 157-168.

Fama, E. (1970). Efficient Capital Markets: A Review of Theory and Empirical Work. The Journal of Finance.

Fawziah, S. A., \& Margasari, N. (2016). The Influence of Fama French Three Factor Model to Stock Return.

FIrmansyah. (2006). Analisis Hubungan Struktur Kepemilikan dengan Kinerja Keuangan Perusahaan Perbankan Persero dan Perusahaan Perbankan Swasta Nasional Go Publik. Fakultas Ekonomi Universitas Islam Indonesia Yogyakarta.

Ghozali, I. (2011). Aplikasi Analisis Multivariate dengan Program SPSS. Semarang: Badan Penerbit Universitas Diponegoro.

Hanafi, Mamduh, M. (2006). Manajemen Risiko. Yogyakarta: UPP STIM YKPN.

Harijanto, C. A., \& Kurniawati, S. L. (2013). Pengujian Market Efficiency: Pembuktian Fenomena Anomali Pasar pada Strait Times Index di Bursa Efek Singapura. Journal of Business and Banking, 223-232.

Hassan, H., \& Kayser, S. (2019). Ramadan effect on stock market return and trade volume: Evidence from Dhaka Stock Exchange (DSE). Cogent Economic \& Finance. 
Hijazi, A., \& Tabash, M. (2020). The Impact of Ramadan month on market stock returns anomalies: an empirical investigation of Palestine Exchange (PEX). Investment Management and Financial Innovation.

Jogiyanto, H. (2017). Teori Portofolio dan Analisis Investasi. Yogyakarta: BPFE.

Kartika, A. (2010). Volatilitas Harfa Saham di Indonesia dan Malaysia. Jurnal Ilmiah Aset.

Lai, Y.-W., \& Windawati, A. (2017). Risk, Return, and Luquidity during Ramadan: Evidence from Indonesian and Malaysian Stock Markets. Research in International Business and Finance.

Nasir, M. A., Khan, K., \& Rossi, M. (2017). The calender anomalies on performance and volatility of stock market: the effects of Ramadan on Karachi Stock Exchange. Global Business and Economics Review.

Sari, L. K., Achsani, N. A., \& Sartono, B. (2017). Pemodelan Volatilitas Return Sagam: Studi Kasus Pasar Saham Asia Modelling Volatility of Return Stock Index: Evidence from Asian Countries. Jurnal Ekonomi dan Pembangunan Indonesia, 35-52.

Saunders, A., \& Cornett, M. M. (2014). Financial Institutions Management. New York: Mc Graw Hill.

Sekaran, U., \& Bougie, R. (2016). Research Methods for Business. United Kingdom: Wiley. Sugiyono. (2003). Metode Penelitian Bisnis. Bandung: Alfabeta.

Sugiyono. (2012). Metode Penelitian Kuantitatif Kualitatif dan $R \& B$. Bandung: Alfabeta. Tandelilin, E. (2010). Portofolio dan Invesasi Teori dan Aplikasi. Yogyakarta: Kanisius. 